Article

\title{
Graduate Students' Experience and Academic Achievements with Online Learning during COVID-19 Pandemic
}

\author{
Halima Ahmed Omar ${ }^{1}$, Eqlima Mohamad Ali ${ }^{1}$ (D) and Shashidhar Belbase ${ }^{2, *(\mathbb{D})}$ \\ 1 Foundations of Education Department, College of Education, United Arab Emirates University, \\ Al Ain P.O. Box 15551, United Arab Emirates; halimaomar616@gmail.com (H.A.O.); \\ 202090145@uaeu.ac.ae (E.M.A.) \\ 2 Department of Curriculum and Instruction, College of Education, United Arab Emirates University, \\ Al Ain P.O. Box 15551, United Arab Emirates \\ * Correspondence: sbelbase@uaeu.ac.ae
}

Citation: Omar, H.A.; Ali, E.M.; Belbase, S. Graduate Students' Experience and Academic Achievements with Online Learning during COVID-19 Pandemic. Sustainability 2021, 13, 13055. https://doi.org/10.3390/su132313055

Academic Editors: Neil Gordon and Han Reichgelt

Received: 21 September 2021 Accepted: 17 November 2021 Published: 25 November 2021

Publisher's Note: MDPI stays neutral with regard to jurisdictional claims in published maps and institutional affiliations.

Copyright: (c) 2021 by the authors. Licensee MDPI, Basel, Switzerland. This article is an open access article distributed under the terms and conditions of the Creative Commons Attribution (CC BY) license (https:// creativecommons.org/licenses/by/ $4.0 /)$.

\begin{abstract}
Higher education institutions in the United Arab Emirates (UAE) adopted a distance/online learning approach during the COVID-19 pandemic in order to ensure that students were safe while they received an uninterrupted, high-quality education off-campus. This was the first time that all of the higher education institutions adopted this approach. Therefore, it is crucial to conduct this study to gain insight into graduate students' experiences in distance learning and to verify whether these experiences are linked to their achievements. The purpose of this study was to examine graduate students' experiences toward online and distance learning during the COVID-19 pandemic in the academic year 2020-2021 and their academic achievement. A questionnaire was developed for this study and sent online to graduate students' emails with the coordination of the College of Graduate Studies at a higher education institution in the UAE. The study received 138 responses. The data was analyzed using IBMSPSS-26. The findings of the study showed that graduate students' level of Engagement, ease of Communication, and quality of learning Experience with online/distance learning were related significantly to their overall academic achievement.
\end{abstract}

Keywords: distance learning; graduate students; academic achievement; COVID-19; UAE; survey

\section{Introduction}

In January 2020, the World Health Organization declared that the COVID-19 outbreak, which is a disease caused by the spread of a novel coronavirus [1], had created a public health emergency with nearly 10,000 people infected and over 200 deaths [2]. As of the end of March 2021, there have been 125,507,698 laboratory-confirmed cases of COVID-19, including 2,755,212 deaths throughout the world [3]. COVID-19 has spread across the globe and crossed all of the boundaries, including the United Arab Emirates.

The first case of COVID-19 in the UAE was identified in January 2020 [3]. In reaction to COVID-19, the UAE government took strict actions aimed at the control of the spread of the virus with precautionary measures. In March 2020, the Federal Authority for Government Human Resources announced remote work for all of the public sector organizations. In addition, the Ministry of Human Resources and Emiratization mandated private sector firms to decrease the in-office workforce by 50\% [4]. In May 2020, the UAE government announced fines ranging from AED 3000-100,000 on individuals that fail to follow the rules and regulations that limit the spread of COVID-19. As of March 2021, the number of laboratory-confirmed cases reached 450,765, including 1472 deaths that were reported to WHO [3].

To control the spread of the COVID-19 pandemic, numerous educational settings in most of the governments around the world have temporarily closed their doors, which has influenced over 70\% of the world's student population [5]. According to UNESCO, 138 countries have closed schools nationwide, impacting over 1.3 billion children and 
youth, among them 1.1 million in UAE schools [5]. In March 2020, the UAE Ministry of Education announced that all of the schools, colleges, and universities across the country would close for 1 month, and distance learning was introduced at the end of the same month. This continued until the end of the academic year 2019-2020 [4]. At the beginning of the academic year 2020-2021, some schools gradually reopened, while higher education institutes continued with distance learning.

Distance learning was initially an adjunct form of education that allowed for virtually instant verification of knowledge and educational activities [6]. Its emergence as a popular approach and a significant supplement to traditional face-to-face learning has been evidenced in the past few years [6]. An increasing number of studies have investigated students' concerns of distance education who use various technologies and receive online pedagogies for learning.

In the late 1980s, early worries about distance learning included the lack of teacher-tolearner interaction, lack of motivation to use technology, and limited tools and theories that support outcome assessment of distance learning [7]. In distance learning, the instructor's role changed into a facilitator role rather than the center of focus as in the traditional classroom [8]. Given the overlapping challenges of distance education, scholars have called for the creation of developmental opportunities that support the staff and students in distance learning and the enhancement of partnerships in order to gain benefits from each other's experiences [9].

Barry [6] found that the factors influencing learning outcomes are students' perceptions of distance learning, educators' ability to provide an effective environment during distance learning, and students' interaction and engagement in the online learning process.

While distance learning has become a familiar approach for the educational environment, evidence in current research on students' experiences of distance learning during COVID-19 in the United Arab Emirates is limited. Furthermore, a small amount of information on the influence of the unforeseen transition from traditional face-to-face to complete distance learning on graduate students' academic achievement is available [6]. Graduate learning has an advanced nature that prepares students for their specialization and helps them develop their critical thinking skills and problem-solving abilities. Therefore, it is important to explore whether distance learning promotes or hinders these skills [10].

The purpose of this study is to explore the experiences of graduate students at a public higher education institution in the United Arab Emirates (UAE) with distance learning, where all of the educational modules were taught using Blackboard and how that influenced their academic achievements. The significance of this study lies in its ability to shed light on students' perceptions of distance/online learning following a sudden shift away from the classroom due to the COVID-19 pandemic, which may give new insights and angles on students' experience. Despite the reported advantages of online asynchronous learning, such as promoting self-regulated learning and supporting collaborative knowledge construction, researchers (i.e., [11]) argue that low contribution rates or lack of engagement in online asynchronous discussions would have a negative influence on students' academic outcomes. Moreover, past research discussed the relatively positive impact of learning intervention factors, e.g., grades, posting guidelines, peer facilitation, and instructor's participation on students' academic achievement [12]. However, these guidelines did not seem sufficient in promoting autonomy, sustained engagement, and performance for all of the students. Therefore, many studies emphasized the need to investigate other factors, such as the social aspects, engagements, emotions, and students' experiences that would yield better results on academic performance $[11,13]$.

\section{Literature Review}

The onset of the COVID-19 pandemic in 2020 has led to the closure of schools and universities across the world, where conventional learning was no longer feasible. In 
addition, educational institutions had to bring forward instant alternative options for their students [14]. The higher education institutions in the United Arab Emirates (UAE) were no exception. All of the teaching and learning processes in the university shifted to distance learning to ensure the continuity of the student's education. This is the first time that the higher education institution, where the study was conducted, has adopted this type of approach, offering a unique and exceptional learning experience to all of the stakeholders in the university. As graduate students are part of this one-of-a-kind cohort, it is imperative to explore the experiences of our fellow students and to determine if they are associated with their academic achievement in any way.

The term distance learning is often used interchangeably with other terms, such as online learning and e-learning [15]. E-learning is defined as "a form of instruction that occurs between two parties (a learner and an instructor), it is held at different times and/or places, and it uses varying forms of instructional materials" ([15], p. 130). While online learning is "access to learning experiences via the use of some technology" ([15], p. 130). Moreover, it is worthy to note that the use of different technologies to create synchronous learning environments for students started decades ago [14]. It began with sharing files and having discussions online. Then, advanced to the use of systems, such as instant chatting and videoconferencing [14]. This review will present the theoretical framework of the study and include the studies that explore students' experiences and academic achievement in distance learning.

Distance learning, which utilizes various technologies including video conferencing, is now the norm in higher education. In addition, distance learning enables the successful delivery of education at convenient times and makes it available for students at different locations [16]. Garrison et al. [16] devised a conceptual framework that identifies various elements that warrant the success of student learning experiences in higher education (see Figure 1). They asserted that a meaningful learning experience is incorporated within a community of inquiry, where teachers and students take part in the educational process and the three elements, which are cognitive, social, and teaching presence, interact together. Moreover, the authors argued that this collaborative community could be created in distance education if all of the three elements are present [16]. The first element, which is cognitive presence, pertains to the ease of communication between participants in the community, such as video conferencing in distance learning [16]. The second element is the extent to which the participants enjoy the presence of others, find the learning experience meaningful in order to remain in the program, and present themselves as "real people" ([16], p. 89). This element is vital as it supports cognitive presence incidentally by enabling critical thinking among the learners [16]. The third element of a successful educational experience is teaching presence, which has two functions that the teacher must carry out [16]. The first function is designing the learning experience, which includes choosing, organizing, and presenting the content; creating meaningful learning activities; and assessing the course [16]. The second function is where the teacher facilitates learning in the video conference, which could include moderating the discussions, recognizing students' input, and providing guidance for the learners. Garrison et al. [16] affirmed that video conferencing, which is utilized in distance learning, has a great capacity to create a community of collaborative learners in higher education if all the elements are in place.

This framework relates to the current study as it provides a platform to devise a student experience questionnaire that surveys students on the use of video conferencing as a tool, for the ease of communication with the teacher and fellow students in online learning, and for the level of their engagement in the class, which pertains to the above-mentioned elements [16]. 


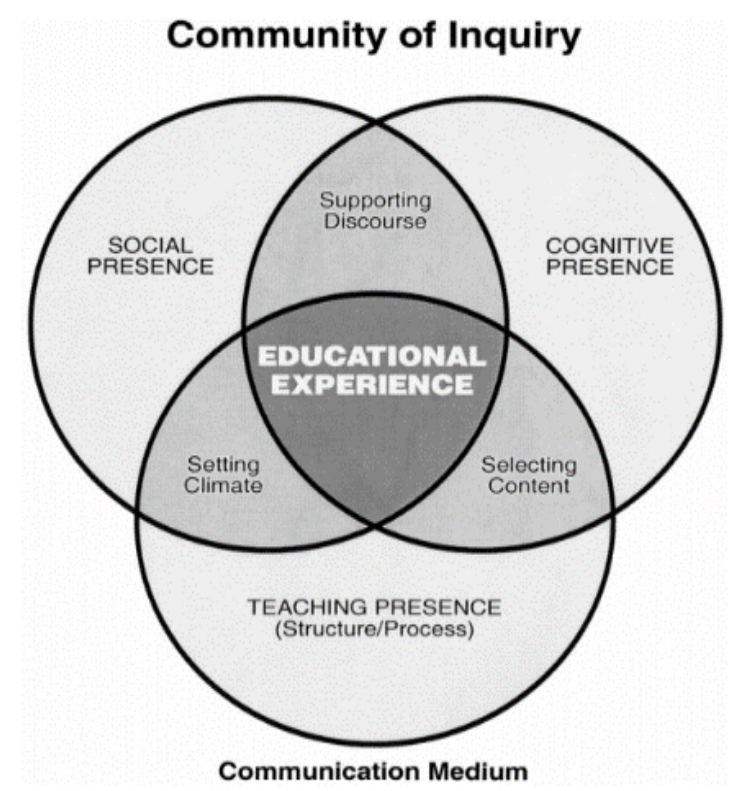

Figure 1. Elements of an educational experience.

\subsection{Student Experiences}

A survey study was conducted in the United States of America (USA) to explore the perceptions of graduate students who were enrolled in online and blended programs in the school of psychology. The research questions included various aspects, such as students' perceptions of online and blended learning, their interests, benefits, and challenges, as well as the impact of online and blended learning on their achievement [11]. Blended learning in this study was defined as "courses that are taught using both online technology and traditional face-to-face instruction" ([11], p. 4). The researchers developed a survey composed of 69 items to measure the students' perceptions based on their positive or negative ratings of different statements on online and blended learning [11]. Students reported that blended learning provided flexibility as not all of them are able to travel to the campus. Moreover, it allowed them to maintain communication with the faculty, increase their content knowledge and engagement, and receive instant feedback on any questions they had. Furthermore, the students affirmed that blended learning had a positive impact on their achievement [11]. A few of the challenges that the students reported regarding learning online as opposed to blended learning include decreased interactions with their fellow students and their instructors, isolation from others, decreased motivation, reduced perseverance, and development of beliefs that online learning has a lower quality in comparison with blended learning [11]. Although the students felt that there were some challenges regarding online learning, most of them reported that this type of learning warranted flexibility, which allowed them to balance their responsibilities towards employment and family [11].

A study by Muir et al. [17] opted to explore students' engagement and their experiences in an online learning 4-year education course offered by an Australian university, using an interpretive qualitative approach. This study differs from the previous one since the authors sent weekly questionnaires via SurveyMonkey over the duration of the course, as well as conducted semi-structed interviews using open-ended questions that were related to various aspects, such as instructors' actions, personal circumstances, learning activities, and challenges that could affect their engagement [17]. Similar to the previous study, students reported that online learning provides a work-life balance, which allows them to cope with their commitments to the course and their families [17]. In addition, students reported that their level of engagement in the course decreased when they had tasks to submit, and they felt that discussion boards were not ideal for encouraging studentto-student interactions [17]. Moreover, students appreciated that their instructors provided 
timely feedback and interesting content [17]. A few of the factors that the study highlighted, which have a great impact on student engagement in online learning, include rapport with the instructor, course requirements, and personal life responsibilities [17].

In a study that was conducted in a public institution in the USA, 86 Master of Arts graduate students who were taught fully online were surveyed, using an instrument that was developed by the researcher to investigate their perceptions on their best experiences [10]. Unlike the previous studies, this study utilized qualitative data only using an open-ended question, which asked the students to mention their best experience and what they learned from it [10]. Students reported that they enjoyed critical thinking assignments that required conducting and writing research, allowing them to develop higher order thinking skills [10]. In addition, students stated that online discussions allowed them to interact, exchange ideas, and connect with their professional peers [10]. Moreover, students reported the ease in communicating with their instructor using emails, phone calls, and synchronous meetings, which enhanced their learning experience [10]. Furthermore, students felt that online learning enhanced their responsibility and time management skills, as they were aware of the requirements needed to improve their performance in the course [10]. Similar to the previous study, students appreciated that the faculty provided timely feedback and reported that it was challenging to work in groups [10].

A qualitative study was conducted at the University of Manchester, UK, which used semi-structured interviews with international students from various countries in the world, who were enrolled in an online Masters degree in public health programme, in order to gain insight into their online learning experiences [18]. This study differs from the previous ones as it focused on students who are geographically situated in different countries and are studying online [18]. In addition, a few of the students in this study confirmed the difficulties in communicating with others and felt that discussion boards are not helpful [18]. Moreover, they affirmed the ease of communicating with their tutors and felt that they were supported [18]. A few of the challenges that were reported included students' expectations of the course to be more flexible, as they thought that they would be able to attend the class whenever they wanted, which was not possible in this course [18]. Other difficulties the students faced included different time zones, lack of coordination when working in groups, and unstable internet connections [18].

Menchaca and Bekele [19] conducted a participatory action research study to explore students' and administrators' views on the success factors of an online learning environment and the technologies used to teach and learn. Seventy-two students who were enrolled in an online Masters program in educational technology and six faculty members were recruited to respond to a survey and follow-up focus groups [19]. Unlike the previous studies, students reported that the use of technology tools, such as emails, forums, and chat allowed them to have relevant and meaningful discussions with their classmates. Students affirmed that the use of various technologies made the course interesting, relevant to their life, and engaging as they noted that they are more inclined to communicate electronically than verbally and this was appropriate for various learning styles [19]. In addition, they reported that the availability of various technologies reduced their sense of isolation and prompted them to prepare for the class since they could access the course syllabi and read ahead of time [19]. A few of the reported challenges included the lack of clarity in the course materials, difficulties in coordinating in-group work, and technical difficulties [19].

These studies, which explored graduate students' experiences in distance and online education, affirmed how students appreciated the ease of communication with their instructors and the timely feedback. Online education seems to enhance student engagement, critical thinking skills, and their sense of responsibility and time management skills. The common challenges reported were difficulties in working and communicating with fellow students, internet connection issues, and feelings of isolation. 


\subsection{Student Academic Achievement}

Since the introduction of online learning, researchers have been interested in how it affects students' learning outcomes and achievement in comparison with face-to-face learning. These competencies could include factual with conceptual and the methodological knowledge required for problem-solving and scientific practices [12]. Paechter and Maier [12] further affirmed that students in universities not only need to acquire conceptual knowledge, but they also need to gain social and personal skills, such as working in teams, self-regulation, and checking their own learning progress in order to improve their skills. This section will include studies on the impact of online learning on learning outcomes.

Kirtman [20] conducted a study to compare the learning outcomes in an online course in comparison with a traditional face-to-face course. Students were enrolled in a Masters program in education, where 71 were taught online and 69 were attending face-to-face classes [20]. The study compared mid-term and final exam scores and grades on two papers that the students submitted [20]. There was no significant difference in the two paper scores between the two groups of students, where the reported $t$-test and $p$-values for the papers were $p$-value $=0.41$ and 0.31 , respectively [20]. However, the study found a significant difference in the mid-term scores, but not the final exam scores between the two groups, where the reported $t$-test and $p$-values were $p$-value $=0.03$ and 0.06 , respectively [20]. The study yielded mixed findings on the difference in scores among students who study online and those who do not.

Another study that was carried out in Scotland and Sweden sought to compare postgraduate students' grades among those who studied online and those who did not [21]. The scores of 164 on campus students and 53 online students in Scotland were compared with the scores of 72 on campus students and 29 online students in Sweden [21]. The study did not find a significant difference in scores by study mode in Scotland, where the reported mean grade scores between the on campus and online students were $M=56.5$ and $\mathrm{M}=59.2$ with a standard deviation of $\mathrm{SD}=8.2$ and $\mathrm{SD}=9.3$, respectively and $t$-test $p$-value $=0.059$ [21]. Similarly, in Sweden, grade distribution among the two groups was the same, in which the reported Mann-Whitney U-test $p$-value was 0.321 [21]. Similar to the previous study, no significant difference was reported in student grades based on the two study modes, which could imply that online learning environments could provide an appropriate and comparable learning experience of on campus learning [21].

In a study that was carried out in Austrian universities, 2196 students who were studying online were surveyed on their learning experiences, assessment of learning achievement, and satisfaction with the experience [12]. The study reported that items in the questionnaire, such as clarity of structure $(\beta=0.228)$ and acquisition of factual and theoretical knowledge $(\beta=0.133)$, contributed to students' satisfaction on their online experience [12]. However, when it comes to learning outcomes, students reported that the advantages of online learning supported their self-regulation skills $(\mathrm{M}=0.88)$, but did not help in acquiring competencies, such as learning knowledge and skills in the subject matter $(\mathrm{M}=-0.43)$, application of their knowledge $(\mathrm{M}=-0.46)$, and communication and cooperation $(\mathrm{M}=-0.63)$ [12]. Paechter and Maier [12] argued that this finding could be attributed to students' preference that face-to-face interaction with the instructor is crucial for knowledge build up. These studies confirmed some advantages of online learning when it comes to self-regulation, but no significant difference in grades was reported in the above studies, which could indicate that distance learning is as effective as traditional learning when it comes to graduate student achievement.

\section{Conceptual Framework and Research Questions}

The conceptual framework integrates four core variables of the study, which are divided into three independent variables and one dependent variable. Independent variables are students' Engagement during online learning (six scale items), overall learning Experience (four scale items), and perceived ease of Communication during online learning (six scale items). While the outcome variable was students' overall academic achievements (nine scale items) (Figure 2). 
Predictor Variables

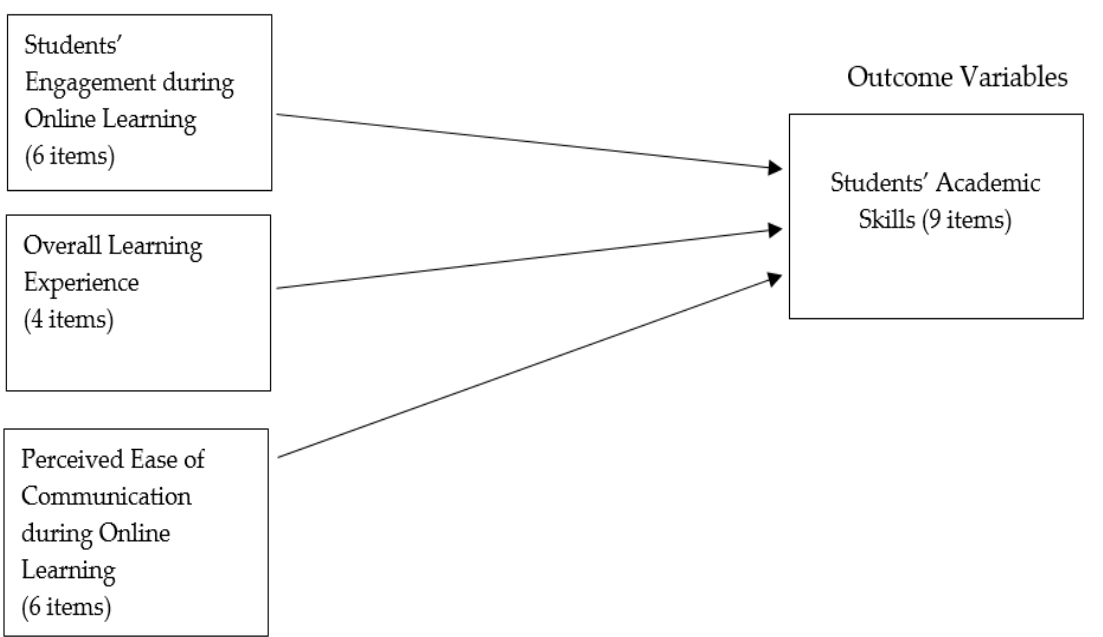

Figure 2. Conceptual framework of independent and dependent variables.

For the purpose of examining this framework, the following three research questions were generated, tested, and discussed throughout the study:

- Does the level of graduate students' engagement with online/distance learning have any influence on their overall academic performance/achievement?

The effectiveness of online learning has been predetermined by the amount of interaction and sense of engagement experienced by online learners [10,22]. According to Mirriahi et al. [23], interaction is a key component in creating a sense of involvement and community for online students. On the other hand, opponents of online schools argue that issues surrounding socialization and connectedness, will always be a concern for learners and educators [22]. Furthermore, there is a shortage of research exploring the influence of engagement levels on learners' academic achievement during online learning [17]. Therefore, investigating and understanding this correlation will assist in providing a framework to increase the quality and levels of engagement amongst learners and educators during distance learning.

- Does the perceived ease of communication of graduate students' during online/distance learning have any influence on their overall academic performance/achievement?

Online learning provides a good opportunity for educators to practice instructional exercises, which mostly encompasses technology [24]. Moreover, Viola et al. [11] suggested that online learning tools are best when they are quite interactive, which encourages learners to be active and independent. Yet, the ease of communication between learners and educators suffers when learners experience a separation in the lines of communication, thus reducing the efficiency of the instruction [23]. To battle the remoteness and enhance the ease of communication in online learning, educators are encouraged to employ creative approaches to maintain as close a connection with online learners as possible [11].

- Does the experience of graduate students with online/distance learning have any influence on their overall academic performance/achievement?

Lately, studies exploring students' perceptions of e-learning have increased. Several research studies suggested that most of the students enrolled in distance learning through online courses are satisfied [17]. Moreover, a study conducted by Yot and Marcelo [24], concluded that there is a significant relationship between the online course structure and student learning outcomes. The data also indicated that student interactions with peers and instructors have a significant influence on students' perception on online learning. However, there is insufficient evidence of the influence of students' experiences with distance learning on their academic performances [24]. 


\section{Methodology}

A cross-sectional quantitative study was adopted where an online questionnaire was sent to graduate students in a public higher education institution in UAE. Cross-sectional studies allowed the collection of data from a student population in a short period of time, which was essential to utilize in this study due to the time constraint [25]. Other advantages of cross-sectional studies include the increase in the likelihood of participation and the ease to conduct a study in an online mode with the purpose of the current study [25].

\subsection{Population and Sample}

To study graduate students' experiences with online/distance learning and to investigate whether this has any influence on their academic achievement, graduate students enrolled in $\mathrm{PhD}$ and Masters programs in a higher education institution in the United Arab Emirates (UAE) were selected as participants for this quantitative research. Out of 1247 graduate students as of spring 2021, a sample of 138 was recruited for this first of its kind research in the UAE [25].

Table 1 shows that the age distribution of the 138 respondents is $54 \%, 42 \%$, and $6 \%$ for $30 \leq 30,31-45$, and $\geq 46$ years, respectively. The male-to-female distribution is $38: 62$, respectively. Over $49 \%$ of the sample is enrolled in the Masters program, while about $51 \%$ is at the PhD level. Out of the 138 respondents, three respondents were removed from the final analysis since they were found to be outliers in the data. Therefore, the final sample consisted of 135 respondents in the survey.

Table 1. Distribution of participants with gender, degree level, and age group.

\begin{tabular}{ccc}
\hline Demographic & Frequency & Percentage \\
\hline Male & 52 & $37.70 \%$ \\
Female & 86 & $62.30 \%$ \\
Masters & 68 & $49.30 \%$ \\
PhD & 70 & $50.7 \%$ \\
Age 1 $(\leq 30)$ & 74 & $54 \%$ \\
Age 2 $(31-45)$ & 58 & $42 \%$ \\
Age 3 $(\geq 46)$ & 6 & $6 \%$ \\
Total & 138 & $100 \%$ \\
\hline
\end{tabular}

\subsection{Construction of the Questionnaire}

The online questionnaire consisted of 28 elements and three sections (see Appendix A). The items in the study were constructed based on the literature review and experiences of the researchers in online learning. Section 1 collected information on graduate students' demographics. Section 2 included statements on the students' experiences of distance learning. Section 3 included statements on students' academic achievement. The participants were prompted to rate the statements using a 4-point Likert scale with strongly disagree (coded 1), disagree (coded 2), agree (coded 3), and strongly agree (coded 4), where a mid-point was not included in order to encourage the participants to report their "true opinion" rather than neutral ([26], p. 3). The questionnaire mainly included four thematic constructs: Engagement, Communication, Experience, and Academic Achievement. Upon examining the internal consistency of each of the four constructs in the questionnaire, three items (items 13,14, and 15) under the third construct (Experience) were found to be suitable for removal as they affected the internal reliability coefficient. Upon removal of these items, the reliability coefficient increased to an acceptable level $(>0.6)$. This certainly affected the result of the study. However, it was deemed necessary to have an acceptable level of reliability coefficient in order to draw valid results from the construct, Experience. Therefore, there were 25 items in the final analysis of questionnaire data. 


\subsection{Data Collection Procedure}

Ethical approval was obtained from The Social Sciences Research Ethics Committee from the United Arab Emirates University. Participants were consented for participation and informed of the study. In addition, detailed information on the significance of the study, the rationale for selecting them as participants, instructions on how to access the online questionnaire, and contact information of the researchers were provided [25]. Confidentiality and anonymity were addressed by not requiring the participants to provide any identifying details, such as names, student ID or emails [25]. The participants were informed on the voluntary nature of participation in the study in the cover letter. In addition, acceptance to continue and withdraw options were included at the start of the online questionnaire and at the end of each section of the online questionnaire [25]. Data collection was done during February to March 2021 in coordination with the Office of Graduate Student Studies at the institution that distributed the online questionnaire. Moreover, the questionnaire was created using Google Forms and the link to the questionnaire was sent via the university email to all of the graduate students who were enrolled in the university. Initially, 77 responses were received at the end of the first week, and after about 2 weeks, a reminder email was sent to the students, which increased the response rate to 138 responses [25]. The questionnaire was distributed to approximately 1100 graduate students who were registered in the spring of 2021, which included all the cohorts continuing their Masters or PhD study at the university.

\subsection{Validity and Reliability}

For the purpose of ensuring the validity and reliability of the collected data from the study sample, relevant statistical tools using the IBM SPSS (version 26) software have been employed by the researchers. Cronbach's alpha test was used to measure the internal consistency amongst the study variables, as well as the reliability of the latent constructs (Table 2). In addition, the confirmatory factor analysis (CFA) technique was applied to examine the degree to which the measured variables explicitly explain their respective latent constructs. The study questionnaire was reviewed by two subject matter experts (Faculty from the College of Education at the higher education institution) and it was piloted with a sample of 16 graduate students for the assessment of clarity, language, ease of instructions, and length [25]. Minor changes to improve readability and comprehension were made following the feedback received [25].

Table 2. Reliability coefficients for the four composite variables (Engagement, Communication, Experience, Achievement) and the overall scale.

\begin{tabular}{cccc}
\hline Constructs & N & No. of Items & Cronbach's $\boldsymbol{\alpha}$ \\
\hline Students' Engagement & 135 & 6 & 0.85 \\
Perceived ease of Communication & 135 & 6 & 0.70 \\
Online learning Experience & 135 & 4 & 0.69 \\
Graduate students' academic Achievement & 135 & 9 & 0.85 \\
Scale reliability & 135 & 25 & 0.92 \\
\hline
\end{tabular}

Prior to conducting the analytical tests, we tested the reliability of 25 elements of the study's questionnaire using Cronbach's alpha test. The results revealed an excellent overall reliability level ( $\alpha=0.92)$ (Table 2$)$. The 25 items in the questionnaire data were divided into four composite factors that reflected the main study variables, which are (1) Graduate students' Engagement with distance/online learning, (2) Perceived ease of Communication with peers and instructors, (3) Graduate students' Experience with online learning, and (4) Graduate students' Academic Achievement acquired during online/distance learning. The internal reliability using Cronbach's alpha test was once again performed for each construct. Table 2 depicts $\alpha$ scores of the internal reliability coefficient, Cronbach's alpha, of 0.85 for Engagement, 0.70 for Communication, 0.69 for Experience, 0.85 for overall academic Achievement, and 0.92 for the overall scale, respectively. 


\section{Results}

One hundred and thirty-eight valid responses were recorded and qualified for data analysis. A snapshot of the demographic profile of the study sample, students' perceptions regarding e-learning, and their academic achievement are presented below. Data were analyzed through a normality test (Table 3), a one-sample Wilcoxon signed rank test (Tables 4-7), the independent samples Mann-Whitney test (Tables 8 and 9), the independent samples Kruskal-Wallis test (Table 10), and a generalized linear model for parameter estimates (Table 11).

Table 3. Test of normality for the variables related to student engagement, communication, online learning experience, and overall academic achievement during online and distance learning.

\begin{tabular}{ccccccc}
\hline \multirow{2}{*}{ Variables } & \multicolumn{3}{c}{ Kolmogorov-Smirnov } & \multicolumn{3}{c}{ Shapiro-Wilk } \\
\cline { 2 - 7 } & Statistic & df & Sig. & Statistic & df & Sig. \\
\hline Engagement & 0.098 & 135 & 0.003 & 0.958 & 135 & 0.000 \\
Communication & 0.082 & 135 & 0.027 & 0.979 & 135 & 0.035 \\
Online Learning Experience & 0.121 & 135 & 0.000 & 0.946 & 135 & 0.000 \\
Overall Academic & 0.119 & 135 & 0.000 & 0.958 & 135 & 0.000 \\
Achievement & & & & & &
\end{tabular}

Table 4. One-sample Wilcoxon signed rank test for students' Engagement in online and distance learning (test value $=2.5$ from the 4-point Likert-scale items).

\begin{tabular}{|c|c|c|c|c|c|c|}
\hline Item No. & Item/Variable & $\mathbf{N}$ & $\begin{array}{c}\text { Test } \\
\text { Statistic }\end{array}$ & $\begin{array}{l}\text { Standard } \\
\text { Error }\end{array}$ & $\begin{array}{l}\text { Standardized } \\
\text { Test Statistic }\end{array}$ & $\begin{array}{l}\text { Asymptotic } \\
\text { Sig. (2-Tailed) }\end{array}$ \\
\hline 1 & I can discuss my ideas freely in the class & 135 & 8430 & 439.28 & 8.74 & 0.000 \\
\hline 2 & I can ask questions freely in the class & 135 & 8797.5 & 441.00 & 9.54 & 0.000 \\
\hline 3 & Classes are engaging & 135 & 7333.5 & 435.25 & 6.30 & 0.000 \\
\hline 4 & I feel motivated to attend the class & 135 & 7389.0 & 438.72 & 6.38 & 0.000 \\
\hline 5 & $\begin{array}{l}\text { Class discussions with other students } \\
\text { enhance my learning experience }\end{array}$ & 135 & 8077.5 & 441.00 & 7.91 & 0.000 \\
\hline 6 & I feel supported in the class & 135 & 6322.5 & 439.28 & 3.94 & 0.000 \\
\hline Engagement & $\begin{array}{l}\text { Level of Student Engagement in Online } \\
\text { and Distance Learning }\end{array}$ & 135 & 7661.0 & 419.72 & 8.42 & 0.000 \\
\hline
\end{tabular}

Table 5. One-sample Wilcoxon signed rank test for ease of Communication in online and distance learning (test value $=2.5$ from the 4-point Likert-scale items).

\begin{tabular}{|c|c|c|c|c|c|c|}
\hline Item No. & Item/Variable & $\mathbf{N}$ & $\begin{array}{c}\text { Test } \\
\text { Statistic }\end{array}$ & $\begin{array}{l}\text { Standard } \\
\text { Error }\end{array}$ & $\begin{array}{l}\text { Standardized } \\
\text { Test Statistic }\end{array}$ & $\begin{array}{c}\text { Asymptotic } \\
\text { Sig. (2-Tailed) }\end{array}$ \\
\hline 7 & $\begin{array}{l}\text { It is easy to communicate with my } \\
\text { instructor in synchronous sessions }\end{array}$ & 135 & 7117.5 & 417.37 & 5.78 & 0.000 \\
\hline 8 & $\begin{array}{l}\text { It is easy to communicate with other } \\
\text { students in online sessions }\end{array}$ & 135 & 5054.5 & 436.16 & 1.07 & 0.287 \\
\hline 9 & $\begin{array}{c}\text { I am more confident in expressing my } \\
\text { ideas in the class when my video is } \\
\text { turned off }\end{array}$ & 135 & 7335.0 & 440.62 & 6.23 & 0.000 \\
\hline 10 & $\begin{array}{c}\text { Class timings are suitable for my work } \\
\text { schedule }\end{array}$ & 135 & 8709.5 & 440.16 & 8.91 & 0.000 \\
\hline 11 & $\begin{array}{c}\text { Interactions with other students in the } \\
\text { class are open }\end{array}$ & 135 & 2631.5 & 437.37 & -4.48 & 0.000 \\
\hline 12 & $\begin{array}{l}\text { It is easy to collaborate with other } \\
\text { students for group work }\end{array}$ & 135 & 5355.0 & 436.58 & 1.75 & 0.080 \\
\hline Communication & $\begin{array}{c}\text { Ease of Communication in Online and } \\
\text { Distance Learning }\end{array}$ & 135 & 5867.0 & 394.34 & 5.21 & 0.000 \\
\hline
\end{tabular}


Table 6. One-sample Wilcoxon signed rank test for graduate students' Experience in online and distance learning (test value $=2.5$ from the 4-point Likert-scale items).

\begin{tabular}{|c|c|c|c|c|c|c|}
\hline Item No. & Item/Variable & $\mathbf{N}$ & $\begin{array}{c}\text { Test } \\
\text { Statistic }\end{array}$ & $\begin{array}{l}\text { Standard } \\
\text { Error }\end{array}$ & $\begin{array}{l}\text { Standardized } \\
\text { Test Statistic }\end{array}$ & $\begin{array}{l}\text { Asymptotic } \\
\text { Sig. (2-Tailed) }\end{array}$ \\
\hline 16 & $\begin{array}{l}\text { I can get information about the course } \\
\text { requirements easily }\end{array}$ & 135 & 8700.0 & 440.62 & 9.33 & 0.000 \\
\hline 17 & $\begin{array}{l}\text { I receive timely feedback from my } \\
\text { instructors on all the assigned work }\end{array}$ & 135 & 7639.0 & 439.01 & 6.95 & 0.000 \\
\hline 18 & $\begin{array}{l}\text { The online teaching application used } \\
\text { in the university is user friendly }\end{array}$ & 135 & 8800.0 & 441.00 & 9.55 & 0.000 \\
\hline 19 & $\begin{array}{c}\text { It is easy to meet my instructor during } \\
\text { office hours }\end{array}$ & 135 & 7398.0 & 435.71 & 6.45 & 0.000 \\
\hline $\begin{array}{c}\text { Online } \\
\text { Learning Exp. }\end{array}$ & $\begin{array}{l}\text { Online and distance learning } \\
\text { experience during COVID-19 }\end{array}$ & 135 & 7666.5 & 403.85 & 9.23 & 0.000 \\
\hline
\end{tabular}

Table 7. One-sample Wilcoxon signed rank test for graduate students' academic Achievement in online and distance learning (test value $=2.5$ from the 4-point Likert-scale items).

\begin{tabular}{|c|c|c|c|c|c|c|}
\hline Item No. & Item/Variable & $\mathbf{N}$ & $\begin{array}{c}\text { Test } \\
\text { Statistic }\end{array}$ & $\begin{array}{l}\text { Standard } \\
\text { Error }\end{array}$ & $\begin{array}{l}\text { Standardized } \\
\text { Test Statistic }\end{array}$ & $\begin{array}{l}\text { Asymptotic Sig. } \\
\text { (2-Tailed) }\end{array}$ \\
\hline 20 & Increased my cumulative GPA & 135 & 5521.5 & 425.84 & 2.19 & 0.029 \\
\hline 21 & Improved my sense of responsibility & 135 & 6806 & 430.80 & 5.14 & 0.000 \\
\hline 22 & Increased my collaboration with others & 135 & 3254.76 & 434.76 & -3.075 & 0.002 \\
\hline 23 & Increased my autonomy & 135 & 8034.5 & 432.62 & 7.96 & 0.000 \\
\hline 24 & improved my creativity & 135 & 5917.5 & 428.09 & 3.10 & 0.002 \\
\hline 25 & $\begin{array}{l}\text { Positively affected my } \\
\text { communication skills }\end{array}$ & 135 & 5752.5 & 431.43 & 2.70 & 0.007 \\
\hline 26 & $\begin{array}{c}\text { Increased my body of knowledge (in all } \\
\text { disciplines) }\end{array}$ & 135 & 6402.5 & 429.49 & 4.22 & 0.000 \\
\hline 27 & Improved my analytical skills & 135 & 6544.5 & 426.61 & 4.58 & 0.000 \\
\hline 28 & Improved my problem-solving skills & 135 & 6613.5 & 430.16 & 4.70 & 0.000 \\
\hline $\begin{array}{c}\text { Academic } \\
\text { Achievement }\end{array}$ & Improved my overall achievement & 135 & 6865.5 & 454.33 & 5.01 & 0.000 \\
\hline
\end{tabular}

Table 8. Independent samples Mann-Whitney U-test (gender).

\begin{tabular}{ccccc}
\hline Statistic & Engagement & Communication & $\begin{array}{c}\text { Online/Dist. } \\
\text { Learning Exp. }\end{array}$ & $\begin{array}{c}\text { Overall Academic } \\
\text { Achievement }\end{array}$ \\
\hline Total N & 135 & 135 & 135 & 135 \\
Mann-Whitney U & 2126.0 & 1940.5 & 2234.0 & 2086.5 \\
Wilcoxon W & 3401.0 & 3215.50 & 3509.0 & 3361.5 \\
Mean Rank (Female, N = 85) & 67.99 & 70.17 & 66.72 & 68.45 \\
Mean Rank (Male, N = 50) & 68.02 & 64.31 & 70.38 & 67.23 \\
Test Statistic & 2126.0 & 1940.5 & 2234.0 & 2086.5 \\
Std. Error & 218.50 & 218.38 & 216.50 & 218.82 \\
Standardized Test Statistic & 0.005 & -0.845 & 0.503 & -0.176 \\
Asymptotic Sig. (2-tail) & 0.996 & 0.398 & 0.615 & 0.860 \\
\hline
\end{tabular}

Table 9. Independent samples Mann-Whitney U-test (degree level-Masters and PhD).

\begin{tabular}{ccccc}
\hline Statistic & Engagement & Communication & $\begin{array}{c}\text { Online/Dist. } \\
\text { Learning Exp. }\end{array}$ & $\begin{array}{c}\text { Overall Academic } \\
\text { Achievement }\end{array}$ \\
\hline Total N & 135 & 135 & 135 & 135 \\
Mann-Whitney U & 2156.5 & 2297.5 & 2250.0 & 2215.5 \\
Wilcoxon W & 4641.5 & 4782.5 & 5035.0 & 4700.5 \\
Mean Rank (Masters, N =65) & 69.82 & 67.65 & 63.77 & 68.92 \\
Mean Rank (PhD, N = 70) & 66.31 & 68.32 & 71.93 & 67.17 \\
Test Statistic & 2156.0 & 2297.5 & 2250.0 & 2215.5 \\
Std. Error & 226.08 & 225.97 & 224.02 & 226.41 \\
Standardized Test Statistic & -0.524 & 0.100 & 1.228 & -0.263 \\
Asymptotic Sig. (2-tail) & 0.600 & 0.921 & 0.220 & 0.793 \\
\hline
\end{tabular}


Table 10. Independent samples Kruskal-Wallis test (across colleges).

\begin{tabular}{|c|c|c|c|c|c|}
\hline Statistic & Engagement & Communication & & Learning Experience & $\begin{array}{c}\text { Overall Academic } \\
\text { Achievement }\end{array}$ \\
\hline Total N & 135 & 135 & & 135 & 135 \\
\hline Test Statistic & 13.95 & 20.62 & & 18.97 & 7.43 \\
\hline Df. & 8 & 8 & & 8 & 8 \\
\hline $\begin{array}{l}\text { Asymptotic } \\
\text { Sig. (2-tail) }\end{array}$ & 0.083 & 0.008 & & 0.015 & 0.491 \\
\hline $\begin{array}{c}\text { Multiple } \\
\text { Comparisons }\end{array}$ & ( & $\begin{array}{l}\text { (1) } \text { Food and Agriculture-Medical and } \\
\text { Health Sciences } \\
\text { (2) } \text { Food and Agriculture-Science } \\
\text { (3) } \text { Food and Agriculture-Information } \\
\text { (4) } \text { Fochnology } \\
\text { (5) Engineering-Science } \\
\text { (6) } \\
\text { Engineering-Education }\end{array}$ & $\begin{array}{l}\text { (1) } \\
\text { (2) } \\
\text { (3) } \\
\text { (4) } \\
\text { (5) } \\
(6)\end{array}$ & $\begin{array}{l}\text { Medicine and Health } \\
\text { Sciences-Education } \\
\text { Medicine and Health } \\
\text { Sciences-Science } \\
\text { Food and Agriculture-Education } \\
\text { Food and Agriculture-Science } \\
\text { Engineering-Education } \\
\text { Engineering-Science }\end{array}$ & NA \\
\hline
\end{tabular}

Note: In all of the above pairs $p<0.05$.

Table 11. Generalized linear model for independent variables (gender, program level, college, engagement, communication, and learning experience) and overall academic achievement as dependent variable.

\begin{tabular}{|c|c|c|c|c|c|c|c|}
\hline \multirow{3}{*}{ Parameter } & \multicolumn{4}{|c|}{ Parameter Estimates } & \multirow[b]{2}{*}{$\begin{array}{c}\text { Hypothesis } \\
\text { Test }\end{array}$} & \multirow[b]{3}{*}{ df } & \multirow[b]{3}{*}{ Sig. } \\
\hline & \multirow{2}{*}{ B } & \multirow{2}{*}{ Std. Error } & \multicolumn{2}{|c|}{$\begin{array}{c}\text { 95\% Wald Confidence } \\
\text { Interval }\end{array}$} & & & \\
\hline & & & Lower & Upper & $\begin{array}{c}\text { Wald } \\
\text { Chi-Square }\end{array}$ & & \\
\hline (Intercept) & 0.203 & 0.2606 & -0.308 & 0.714 & 0.605 & 1 & 0.437 \\
\hline$[$ Gender $=0]$ & -0.037 & 0.0754 & -0.185 & 0.110 & 0.244 & 1 & 0.621 \\
\hline$[$ Gender $=1]$ & $0^{\mathrm{a}}$ & & & & & & \\
\hline [Program Level = Masters $]$ & 0.070 & 0.0814 & -0.089 & 0.230 & 0.742 & 1 & 0.389 \\
\hline$[$ Program Level $=\mathrm{PhD}]$ & $0^{\mathrm{a}}$ & & & & & & \\
\hline [College $=$ Business and Economics $]$ & 0.144 & 0.2780 & -0.400 & 0.689 & 0.270 & 1 & 0.603 \\
\hline$[$ College $=$ Education $]$ & 0.093 & 0.1147 & -0.132 & 0.318 & 0.660 & 1 & 0.417 \\
\hline [College = Engineering] & 0.048 & 0.0959 & -0.140 & 0.236 & 0.250 & 1 & 0.617 \\
\hline [College $=$ Food and Agriculture $]$ & 0.233 & 0.1377 & -0.037 & 0.502 & 2.854 & 1 & 0.091 \\
\hline [College $=$ Humanities and Social Science $]$ & 0.424 & 0.1971 & 0.038 & 0.810 & 4.626 & 1 & 0.031 \\
\hline [College = Information Technology] & 0.223 & 0.1684 & -0.107 & 0.553 & 1.749 & 1 & 0.186 \\
\hline$[$ College $=$ Law $]$ & 0.080 & 0.2763 & -0.461 & 0.622 & 0.084 & 1 & 0.772 \\
\hline [College $=$ Medicine and Health Sciences $]$ & 0.158 & 0.1168 & -0.071 & 0.387 & 1.836 & 1 & 0.175 \\
\hline [College $=$ Science $]$ & $0^{\mathrm{a}}$ & & & & & & \\
\hline Engagement & 0.298 & 0.0810 & 0.140 & 0.457 & 13.564 & 1 & 0.000 \\
\hline Communication & 0.332 & 0.0874 & 0.161 & 0.504 & 14.477 & 1 & 0.000 \\
\hline Online Learning Experience & 0.186 & 0.0744 & 0.040 & 0.332 & 6.232 & 1 & 0.013 \\
\hline
\end{tabular}

a, Set to zero because this parameter is redundant.

The Kolmogorov-Smirnov and Shapiro-Wilk tests of normality for the variables in Table 3 showed that the four variables that were related to online and distance learning during the COVID-19 pandemic were not normally distributed $(p<0.05)$. Therefore, the remaining the tests were performed using non-parametric tests (e.g., one-sample Wilcoxon signed rank test, Mann-Whitney U-test, and Kruskal-Wallis test).

Figure 3 shows the distribution of minimum, three quartiles, and maximum values for the four thematic constructs-Engagement, Communication, Experience, and Achievement. The distribution of quartiles showed that the median (or the second quartile) values vary across the four themes and also from the ideal mid-value of 2.5 from the Likert-scale. The second quartile of all the thematic constructs is greater than the mid-value of 2.5 on the scale. This signified that the actual medians are greater than the hypothesized median. To examine whether these differences were statistically significant, the one-sample Wilcoxon signed rank tests were performed (Tables $4-7$ ). The results for each thematic area have been discussed below. 


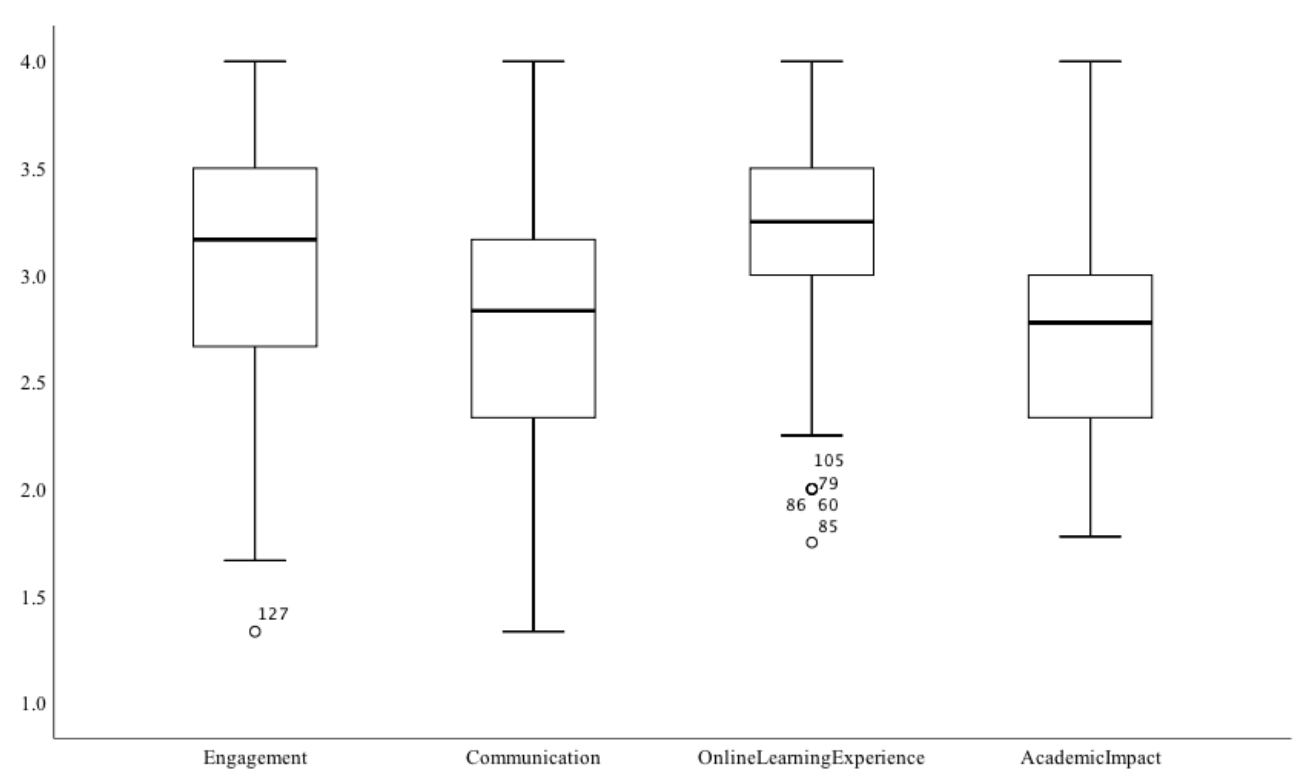

Students' achievement variables in online learning.

Figure 3. Box plot for graduate students' Engagement, ease of Communication, online and distance learning Experience, and academic Achievement.

\subsection{Graduate Students' Engagement in Online and Distance Learning}

Table 4 shows the results of the one-sample Wilcoxon signed rank test for graduate students' Engagement in online and distance learning during the COVID-19 pandemic, in a higher education institution in the UAE in the spring semester of the academic year 20202021. The results showed that the graduate students had positive views of their Engagement in online and distance learning during the COVID-19 pandemic. Their view "I can discuss my ideas freely in the class" was statistically significant $(\mathrm{z}=8.74, p=0.000<0.05)$. Likewise, their views on "asking questions", "engaging class", "motivation", "discussion", and "supported in class" were all statistically significant at the 0.05 level of significance. The overall composite scale level of student Engagement in online and distance learning was statistically significantly positive $(\mathrm{z}=8.42, p=0.000<0.05)$ (Table 4$)$.

An independent sample Mann-Whitney U-test (Table 8) for graduate student Engagement in online and distance learning showed that there was no statistically significant difference between the male and female students in terms of their engagement in virtual classes (Female: Mean Rank $=67.99, n=85$; Male: Mean Rank $=68.02, n=50 ; \mathrm{z}=0.005$ and $p=0.996>0.05)$. Similarly, there was no statistically significant difference between the Masters and PhD students in terms of their Engagement in virtual classes (Masters: Mean Rank $=69.82, n=65 ;$ PhD: Mean Rank $=66.31, n=70 ; \mathrm{z}=-0.524$ and $p=0.600>0.05$ ) (Table 9). The Kruskal-Wallis test (Table 10) for graduate students' Engagement in online and distance learning across the colleges was found to be statistically not significant $(\mathrm{z}=13.95, \mathrm{df}=8, p=0.083>0.05)$. However, the level of Engagement in online and distance learning was a significant predictor of graduate students' academic Achievement $(\mathrm{B}=0.298, p=0.000<0.05)($ Table 11$)$.

\subsection{Graduate Students' Perception towards the Ease of Communication in Online and Distance Learning}

Table 5 shows the results of the one-sample Wilcoxon signed rank test for graduate students' ease of Communication in online and distance learning during the COVID-19 pandemic, in a higher education institution in the UAE in the spring semester of academic year 2020-2021. The results showed that the graduate students had mixed views on the ease of their Communication with faculty and other students in online and distance learning during the COVID-19 pandemic. Their view on "it is easy to communicate with my instructor 
in synchronous sessions" was statistically significantly positive $(\mathrm{z}=5.78, p=0.000<0.05)$. However, their view on "it is easy to communicate with other students in online sessions" was neutral $(z=1.07, p=0.287>0.05)$. Likewise, their view was neutral regarding "it is easy to collaborate with other students for group work" $(z=1.75, p=0.08>0.05)$. The graduate students positively perceived the statement "I am more confident in expressing my ideas in the class when my video is turned off" $(\mathrm{z}=6.23, p=0.000<005)$, and "class timings are suitable for my work schedule" $(\mathrm{z}=8.91, p=0.000<005)$. Nonetheless, they had a negative view towards the statement, "interactions with other students in the class are open" $(\mathrm{z}=-4.48, p=0.000<0.05)$. The overall composite value for ease of Communication showed that graduate students' experience was positive for Communication in online and distance learning during the COVID-19 pandemic $(z=5.21, p=0.000<0.05)$ (Table 5).

An independent sample Mann-Whitney U-test (Table 8) for graduate students' feeling on the ease of Communication in online and distance learning showed that there was no statistically significant difference between the male and female students in terms of ease of Communication in virtual classes (Female: Mean Rank =70.17, $n=85$; Male: Mean Rank $=64.31, n=50 ; \mathrm{z}=-0.845$ and $p=0.921>0.05)$. Similarly, there was no statistically significant difference between the Masters and $\mathrm{PhD}$ students in terms of ease of Communication in virtual classes (Masters: Mean Rank $=67.65, n=65$; PhD: Mean Rank $=68.32, n=70 ; \mathrm{z}=0.100$ and $p=0.921>0.05)$ (Table 9). The Kruskal-Wallis test (Table 10) for graduate students' perception of ease of Communication in online and distance learning across the colleges was found to be statistically significant $(z=20.62$, $\mathrm{df}=8, p=0.008<0.05)$. The differences were observed between the College of Food and Agriculture with the Medical and Health Sciences, Science, Information Technology, and Education $(p<0.05)$. Likewise, there was a significant difference between the students of the College of Engineering and Science and Education regarding their perception of the ease of Communication $(p<0.05)$. Their perception of the ease of Communication was a significant predictor of academic Achievement $(\mathrm{B}=0.332, p=0.000<0.05)$ (Table 11).

An independent sample Mann-Whitney U-test (Table 8) for graduate students' feelings on the ease of Communication in online and distance learning showed that there was no statistically significant difference between the male and female students in terms of ease of Communication in virtual classes (Female: Mean Rank $=70.17, n=85$; Male: Mean Rank $=64.31, n=50 ; z=-0.845$ and $p=0.921>0.05)$. Similarly, there was no statistically significant difference between the Masters and $\mathrm{PhD}$ students in terms of ease of Communication in virtual classes (Masters: Mean Rank $=67.65, n=65 ;$ PhD: Mean Rank $=68.32$, $n=70 ; z=0.100$ and $p=0.921>0.05$ ) (Table 9). The Kruskal-Wallis test (Table 10) for graduate students' perception of ease of Communication in online and distance learning across the colleges was found to be statistically significant $(\mathrm{z}=20.62, \mathrm{df}=8, p=0.008<0.05)$.

\subsection{Graduate Students' Perception towards Online and Distance Learning Experience}

Table 6 shows the results of the one-sample Wilcoxon signed rank test for graduate students' online and distance learning Experience during the COVID-19 pandemic, in a higher education institution in the UAE in the spring semester of academic year 20202021. The results showed that the graduate students had overall statistically significant positive views on their Experience of online and distance learning during the COVID-19 pandemic $(z=9.23, p=0.000<0.05)$. Moreover, the results showed that their view on "I can get information about the course requirements easily" was statistically significantly positive $(z=9.33, p=0.000<0.05)$. Furthermore, they had a statistically significant positive Experience regarding "teacher feedback", "online teaching application tool", and "meeting time with teachers" $(p<0.05)$ (Table 6).

An independent sample Mann-Whitney U-test (Table 8) for graduate students' Experience in online and distance learning showed that there was no statistically significant difference between the male and female students in terms of their Experience in virtual classes (Female: Mean Rank $=66.72, n=85$; Male: Mean Rank $=70.38, n=50 ; \mathrm{z}=0.503$ and $p=0.615>0.05)$. Similarly, there was no statistically significant difference between the 
Masters and PhD students in terms of quality of learning Experience in online and distance classes (Masters: Mean Rank $=63.77, n=65$; PhD: Mean Rank $=71.93, n=70 ; \mathrm{z}=0.1228$ and $p=0.220>0.05$ ) (Table 9). The Kruskal-Wallis test (Table 10) for graduate students' Experience in online and distance learning across the colleges was found to be statistically significant $(\mathrm{z}=18.97 \mathrm{df}=8, p=0.015<0.05)$. The differences were observed between the College of Medical and Health Sciences and Science, College of Medical and Health Sciences and Education, College of Food and Agriculture and Education, College of Food and Agriculture and College of Science, College of Engineering and Education, and College of Engineering and Science $(p<0.05)$. The graduate students' Experience in online and distance learning was a significant predictor of their academic Achievement $(B=0.186$, $p=0.013<0.05)($ Table 11$)$.

\subsection{Graduate Students' Academic Achievement during Online and Distance Learning}

Table 7 shows the results of the one-sample Wilcoxon signed rank test for graduate students' academic Achievement of online and distance learning during the COVID-19 pandemic, in a higher education institution in the UAE in the spring semester of academic year 2020-2021. The results showed that the graduate students had overall statistically significant positive views on their academic achievement of online and distance learning during the COVID-19 pandemic $(\mathrm{z}=5.01, p=0.000<0.05)$. Moreover, the results showed that their view on "increased my cumulative GPA" was statistically significantly positive $(\mathrm{z}=2.19, p=0.029<0.05)$. Furthermore, they had statistically significantly positive views regarding "sense of responsibility", "autonomy", "creativity", "communication skills", "body of knowledge", "analytical skills", and "problem solving skills" $(p<0.05)$ (Table 7). Despite the several positive achievements of online and distance learning, the graduate students' academic achievement in terms of collaboration with other students was significantly negatively impacted during online and distance learning $(\mathrm{z}=-3.075$, $p=0.002)$.

An independent sample Mann-Whitney U-test (Table 8) for graduate students' academic Achievement in online and distance learning showed that there was no statistically significant difference between the male and female students in terms of their academic Achievement in online and distance classes (Female: Mean Rank $=6845, n=85$; Male: Mean Rank $=67.23, n=50 ; z=-0.176$ and $p=0.860>0.05)$. Similarly, there was no statistically significant difference between the Masters and PhD students in terms of academic Achievement in online and distance learning during the COVID-19 pandemic (Masters: Mean Rank = 68.92, $n=65 ;$ PhD: Mean Rank =67.17, $n=70 ; \mathrm{z}=-0.263$ and $p=0.793>0.05$ ) (Table 9). The Kruskal-Wallis test (Table 10) for graduate students' academic Achievement in online and distance learning across the colleges was found to be statistically not significantly different $(\mathrm{z}=7.43, \mathrm{df}=8, p=0.491>0.05)$. The graduate students' academic Achievement in online and distance learning was significantly impacted by their level of Engagement $(\mathrm{B}=0.298, p=0.000<0.05)$, ease of Communication $(\mathrm{B}=0.332, p=0.000<0.05)$, and learning Experience $(\mathrm{B}=0.186, p=0.013<0.05)$ (Table 11). Among the demographic variables, only one variable, the college of Humanities and Social Sciences, was a significant predictor of graduate students' academic Achievement among all of the other colleges $(\mathrm{B}=0.424, p=0.031<0.05)($ Table 11$)$.

\section{Discussion}

The overall composite scale level of student Engagement in online and distance learning was statistically significantly positive $(z=8.42, p=0.000<0.05)$. This finding indicated that the graduate students were engaged in the learning process during their online and distance sessions through different means or tools that supported the teacherto-student interaction and the dissemination of ideas, skills, and knowledge. The facultyto-student interaction has been identified as a significant factor in student satisfaction and positive feelings of their participation in virtual classes [27-29]. Student engagement has been reported as one of the essential factors of success and positive impact of online and 
distance learning during the COVID-19 pandemic [29]. The level of student-to-student interaction was found to be weak with a negative impact on student collaboration. In addition, this finding is consistent with the one found in Khan et al. [29]. However, the level of Engagement in online and distance learning was a significant predictor of graduate students' academic Achievement $(\mathrm{B}=0.298, p=0.000<0.05)$. The level of student engagement in online and distance learning has a positive effect on students' overall performance, including the GPA during the COVID-19 lockdown [30]. However, if the students perceived that their engagement during the lockdown period in online and distance learning was not as engaging as face-to-face sessions, then their overall performance, including the GPA, might be affected negatively [30].

The results showed that the graduate students had mixed views on the ease of their Communication with faculty and other students in online and distance learning during the COVID-19 pandemic. In addition, the findings showed that the participants found it easy to communicate with the instructors in synchronous sessions. However, they found difficulty in communicating with the other students in online sessions. There could be a possibility that the students had an opportunity to interact with faculty members directly during the teaching and learning sessions or in the virtual office hours. This flexibility, of the students to interact with each other, was not offered through the online platforms or learning systems. Numerous class sessions could have been designed for the faculty-to-student connection through the learning management systems applied in the institution. However, only a few faculty members might have used discussion threads or blogs for the student interaction. These interactions are essential for the social presence of students and teachers. There is a great impact on the social presence of students for their learning and development in higher education [31], especially when using online and distance education as a mode of learning during the COVID-19 pandemic. The graduate students' perception of the ease of Communication in online and distance learning across the colleges was found to be statistically significant. In addition, the literature supports this finding [32]. The pattern of communication in online and distance learning may provide flexibility in terms of time of communication, mode of communication, and interaction between the teachers and students [33]. In the current study, it was found that graduate students' perception of the ease of Communication was a significant predictor of academic Achievement. These achievements could be in terms of academic grades, self-confidence, clarity, creativity, collaboration, and comprehension of ideas [34]. Moreover, the result of the current study showed that the graduate students had overall statistically significant positive views on their Experience of online and distance learning during the COVID-19 pandemic, despite the challenges in collaboration and communication among the students. Students' positive experience of online and distance learning have a significant impact on their overall academic performance [35].

The literature on online and distance learning reports had mixed results on student performance. A few studies report that there is no significant achievement in online and distance learning compared with face-to-face learning [36,37]. The results showed that the graduate students had overall statistically significant positive views on their academic Achievement from online and distance learning during the COVID-19 pandemic. In addition, the results showed that their view on "increased my cumulative GPA" was statistically significantly positive. The literature shows that students with higher GPAs performed better with face-to-face learning during online and distance learning. However, students with lower GPAs could not perform well in the online classes compared with the face-to-face mode [29]. This result showed that the findings regarding student achievement in online learning during the COVID-19 pandemic were not conclusive.

Graduate students' experience with distance/online learning in the aspect of engagement during online learning, perceived ease of communication, and overall online experience, is statistically significantly correlated with their academic achievement. The study concluded that students learn most through engagement and that students' learning 
and academic outcomes are directly related to students' quality and quantity of involvement in the learning experience [13].

These findings indicate that students' ease of communication with peers and instructors during online learning have the strongest association with students' academic skills. Moreover, general learning experiences and engagement have strong and significant correlations with academic skills. Chemers, Hu, and Garcia [38] obtained similar results in their study that revealed a positive association between students' general experience through online course progression and their academic performance. Furthermore, authors concluded that students who had more positive experiences performed significantly better academically, as measured by the GPA [38]. The generalized linear model partially supports the previous results in that students with higher Engagement, ease of Communication, and overall positive learning Experience during the COVID-19 pandemic are more likely to have higher academic performance than the pre-pandemic period. This specific outcome is supported by the theory of student development, which states that students' learning and development outcomes are directly proportional to the student involvement in the learning experience [13].

\section{Strength and Limitations}

This is the first study at a public higher education institution in the UAE during the post-rapid shift to distance learning in response to the COVID-19 pandemic. In addition to its novelty, significant results were derived with regards to the core study variables. This study was able to produce a unique finding with regards to graduate students' engagement, communication, learning experience association with gender, academic level, and across colleges with respect to the level of engagement, ease of communication, and quality of learning experience. The generalized linear model revealed that graduate students' demographics did not impact their overall academic performance. However, the quality of engagement, communication, and learning experiences did have a significant impact on their overall academic development and performance during online and distance learning. In addition, the findings suggest that faculty members in higher education institutions should create a virtual environment for student-to-student interactions and their social presence in the learning process. Distance or online learning can be a good option during the crisis that prevents the physical or face-to-face presence of teachers and students in the classroom [39]. However, the quality of students' learning and development must be a top priority with all of the possible means in distance learning. A successful online course relies on the degree to which learners and educators can operate the online learning tools [40]. It is suggested to be an area of future scholarly investigation and follow up. Despite the strong areas of this study, a few limitations are present. First, the lack of sample randomization, which may be the reason for not obtaining significant demographics' associations with the study core variables. Second, the study questionnaire did not allow the participants to give explanations or reasons for their responses. Third, specific questions that potentially have an influence on academic achievement, such as students' access to devices, high speed internet, and a sufficient study space, were not included in the study questionnaire. Finally, due to the time constraints, this study used a quantitative approach, which could be supplemented by a mixed method approach study in order to gain a more comprehensive understanding and implications of the study's key areas.

\section{Conclusions and Recommendations}

This study investigated the influence of distance/online learning experiences on the academic achievement of graduate students in a public higher education institution in the UAE. A simple random sample of 138 students participated in the open call for participation in the study. The non-parametric one-sample Wilcoxon signed rank test, independent samples Mann-Whitney U-test, independent samples Kruskal-Wallis test, and generalized linear model were performed on the data using IBM SPSS-26. With regards to the study's core variables, three independent variables (Engagement during online 
learning, overall learning Experience, and perceived ease of Communication during online learning) were proven to be statistically significantly correlated with graduate students ${ }^{\prime}$ overall academic skills. These findings were generally supported by the findings of the generalized linear model. Therefore, it is suggested that the three factors of students ${ }^{\prime}$ overall experience (Engagement, Communication, and Experience) are strong predictors of academic achievement and are an area of focus in the research field, since few studies in the past considered the three constructs together. Other institutions may benefit from these findings when designing distance learning programs, where efforts to ensure high student engagement, effective communication, and positive experiences could be the foundation of a successful teaching and learning experience. The study could be extended to other higher education institutions in order to achieve generalizable findings with a large sample of graduate and undergraduate students.

Author Contributions: Conceptualization, H.A.O. and E.M.A.; methodology, H.A.O. and E.M.A.; software, S.B.; validation, H.A.O., E.M.A. and S.B.; formal analysis, S.B.; investigation, E.M.A.; resources, H.A.O.; data curation, S.B.; writing-original draft preparation, H.A.O. and E.M.A.; writing-review and editing, H.A.O., E.M.A. and S.B.; visualization, S.B.; supervision, S.B.; project administration, E.M.A.; funding acquisition, S.B. All authors have read and agreed to the published version of the manuscript.

Funding: The APC for this publication was supported by the College of Education, United Arab Emirates University under the Faculty Startup Research Grant No. 12D004.

Institutional Review Board Statement: The study was conducted according to the guidelines of the Declaration of Helsinki, and approved by the Research Ethics Committee of the United Arab Emirates University (protocol code ERS-2021-7266 and date of approval 2 March 2021).

Informed Consent Statement: Informed consent was obtained from all subjects involved in the study.

Data Availability Statement: The data for this study is not publicly available. However, it can be proved upon request.

Conflicts of Interest: The authors declare no conflict of interest in publication of this article.

\section{Appendix A}

\section{Study Questionnaire}

Graduate Students' Experience and Academic Achievements with Online Learning during the COVID-19 Pandemic.

\section{Section (1) Demographic Information:}

1. Gender: Male, Female

2. Age Group: 24 years and below, 25-30 years, 31-35 years, 36-40 years, $41-45$ years, 46-50 years, 51 years and above.

3. Year of joining to the Graduate Program: 2016/2017/2018/2019/2020/2021

4. Program level: Masters, $\mathrm{PhD}$

5. Collage Name: Business and Economics/Education/Engineering/Food and Agriculture/Humanities and Social Science/Information Technology/Law/Medicine and Health Sciences/Science/other

6. Year Level: 1st year, 2nd year, 3rd year, 4th year

7. Enrollment Status: Full-time, Part-time, other

8. Employment Status: Not Employed/Full-time/Part-time

9. Nationality: (drop-list of nationalities will be created)

\section{Section (2) Graduate Students Experiences in Distance Learning:}

This section of the questionnaire relates to your experiences in distance learning.

Please indicate your degree of agreement with the following statements. 


\begin{tabular}{|c|c|c|c|c|}
\hline Themes & In Distance and Online Learning & $\begin{array}{l}\text { Strongly } \\
\text { Agree }\end{array}$ & Agree Disagree & $\begin{array}{l}\text { Strongly } \\
\text { Disagree }\end{array}$ \\
\hline \multirow{6}{*}{$\begin{array}{c}\text { Students' } \\
\text { engagement }\end{array}$} & 1. I can discuss my ideas freely in the class & & & \\
\hline & 2. I can ask questions freely in the class & & & \\
\hline & 3. Classes are engaging & & & \\
\hline & 4. I feel motivated to attend the class & & & \\
\hline & $\begin{array}{l}\text { 5. Class discussions with other students enhance my } \\
\text { learning experience }\end{array}$ & & & \\
\hline & 6. I feel isolated in the class & & & \\
\hline \multirow{6}{*}{$\begin{array}{l}\text { Perceived ease of } \\
\text { communication }\end{array}$} & $\begin{array}{l}\text { 7. It is difficult to communicate with my instructor in } \\
\text { synchronous sessions }\end{array}$ & & & \\
\hline & $\begin{array}{l}\text { 8. It is difficult to communicate with other students in } \\
\text { online sessions }\end{array}$ & & & \\
\hline & $\begin{array}{l}\text { 9. I am more confident in expressing my ideas in the class } \\
\text { when my video is turned off }\end{array}$ & & & \\
\hline & 10. Class timings are suitable for my work schedule & & & \\
\hline & 11. Interactions with other students in the class are limited & & & \\
\hline & 12. It is easy to collaborate with other students for group work & & & \\
\hline \multirow{7}{*}{$\begin{array}{l}\text { Online learning } \\
\text { experience }\end{array}$} & 13. Class recordings make learning more accessible & & & \\
\hline & $\begin{array}{l}\text { 14. Technology glitches during the class disturb the flow } \\
\text { of information }\end{array}$ & & & \\
\hline & 15. Different learning styles are NOT accommodated & & & \\
\hline & 16. I can get information about the course requirements easily & & & \\
\hline & $\begin{array}{l}\text { 17. I receive timely feedback from my instructors on all the } \\
\text { assigned work }\end{array}$ & & & \\
\hline & $\begin{array}{l}\text { 18. The online teaching application used in university is } \\
\text { user friendly }\end{array}$ & & & \\
\hline & 19. It is easy to meet my instructor during his office hours & & & \\
\hline
\end{tabular}

\section{Section (3) Graduate Students Achievement:}

This section of the questionnaire relates to student achievement. Please indicate your degree of agreement with the following statements.

\begin{tabular}{|c|c|c|c|c|}
\hline Themes & Distance/Online Learning Has ... & $\begin{array}{c}\text { Strongly } \\
\text { Agree }\end{array}$ & Agree Disagree & $\begin{array}{l}\text { Strongly } \\
\text { Disagree }\end{array}$ \\
\hline \multirow{9}{*}{$\begin{array}{l}\text { Impact on } \\
\text { Academic } \\
\text { Performance }\end{array}$} & 20. Increased my cumulative GPA & & & \\
\hline & 21. Improved my sense of responsibility & & & \\
\hline & 22. Reduced my collaboration with others & & & \\
\hline & 23. Increased my autonomy & & & \\
\hline & 24. Improved my creativity & & & \\
\hline & 25. Negatively affected my communication skills & & & \\
\hline & 26. Increased my body of knowledge (in all of the disciplines) & & & \\
\hline & 27. Improved my analytical skills & & & \\
\hline & 28. Improved my problem-solving skills & & & \\
\hline
\end{tabular}

Thank you for your participation and time. 


\section{References}

1. Bender, L. Key Messages and Actions for COVID-19 Prevention and Control in Schools; UNICEF: New York, NY, USA, 2020; Available online: https:/ / tinyurl.com/eyrn44a (accessed on 25 April 2021).

2. Mahase, E. China coronavirus: WHO declares international emergency as death toll exceeds 200. BMJ 2020, 368, m408. [CrossRef]

3. World Health Organization (WHO). Coronavirus Disease (COVID-19) Advice for the Public. 2021. Available online: https: //www.who.int/emergencies/diseases/novel-coronavirus2019/advice-for-public (accessed on 25 April 2021).

4. UAE Ministry of Cabinet Affairs and The Future. Successful "Distance Learning" for 1.2 Million Students Leveraging UAE's Futuristic Vision, Flexibility and Advanced Infrastructure. 2020. Available online: https://www.mocaf.gov.ae/ en/media/news/successful-distance-learningfor-1.2-million-students-leveraging-uae-s-futuristic-vision-flexibility-andadvancedinfrastructure (accessed on 28 April 2021).

5. United Nations Educational, Scientific and Cultural Organization (UNESCO). Global Monitoring of School Closures Caused by COVID-19. 2020. Available online: https:/ / en.unesco.org/covid19/educationresponse (accessed on 2 May 2021).

6. Barry, J. This Is What a Real Emergency Looks Like: What the Response to Coronavirus Can Teach Us about How We Can and Need to Respond to the Planetary Emergency; Green House Think Tank: Lancaster, UK, 2020; Available online: https://tinyurl.com/2ct7vtpw (accessed on 14 April 2021).

7. Fernandez, C.; Cannon, J.; Chokshi, S.M. A US-Japan lesson study collaboration reveals critical lenses for examining practice. Teach. Teach. Educ. 2003, 19, 171-185. [CrossRef]

8. Harland, T.; Staniforth, D. A family of strangers: The fragmented nature of academic development. Teach. High. Educ. 2008, 13, 669-678. [CrossRef]

9. Cox, M.D. Fostering the scholarship of teaching and learning through faculty learning communities. J. Excell. Coll. Teach. 2003, 14, 161-198. Available online: http:/ / celt.miamioh.edu/ject/issue.php?v=14\&n=2\%20and\%203 (accessed on 20 April 2021).

10. Holzweiss, P.; Joyner, S.; Fuller, M.; Henderson, S.; Young, R. Online graduate students' perceptions of best learning experiences. Distance Educ. 2014, 35, 311-323. [CrossRef]

11. Viola, S.; Saeki, E.; Hendricker, E. Distance education in graduate training programs: Lessons learned from school psychology students. J. Educ. Online 2019, 16, 1-17. Available online: https://eric.ed.gov/?id=EJ1223939 (accessed on 20 April 2021). [CrossRef]

12. Paechter, M.; Maier, B. Online or face-to-face? Students' experiences and preferences in e-learning. Internet High. Educ. 2010, 13, 292-297. [CrossRef]

13. Vollet, J.W.; Kindermann, T.A.; Skinner, E.A. In peer matters, teachers matter: Peer group influences on students' engagement depend on teacher involvement. J. Educ. Psychol. 2017, 109, 635-652. [CrossRef]

14. Bonk, C. Pandemic ponderings, 30 years to today: Synchronous signals, saviours, or survivors? Distance Educ. 2020, 41, 589-599. [CrossRef]

15. Moore, J.; Dickson-Deane, C.; Galyen, K. e-Learning, online learning, and distance learning environments: Are they the same? Internet High. Educ. 2011, 14, 129-135. [CrossRef]

16. Garrison, R.; Anderson, T.; Archer, W. Critical Inquiry in a Text-Based Environment: Computer Conferencing in Higher Education. Internet High. Educ. 2000, 2, 87-105. [CrossRef]

17. Muir, T.; Milthorpe, N.; Stone, C.; Dyment, J.; Freeman, E.; Hopwood, B. Chronicling engagement: Students' experience of online learning over time. Distance Educ. 2019, 40, 262-277. [CrossRef]

18. Harrison, R.; Harrison, A.; Robinson, C.; Rawlings, B. The experience of international postgraduate students on a distance learning programme. Distance Educ. 2018, 39, 480-494. [CrossRef]

19. Menchaca, M.; Bekele, T. Learner and instructor identified success factors in distance education. Distance Educ. 2008, $29,231-252$. [CrossRef]

20. Kirtman, L. Online versus in-class courses: An examination of differences in learning outcomes. Issues Teach. Educ. 2009, 18, 103-116. Available online: https:/ / files.eric.ed.gov/fulltext/EJ858508.pdf. (accessed on 23 March 2021).

21. McPhee, I.; Soderstrom, T. Distance, online and campus higher education: Reflections on learning outcomes. High. Educ. 2012, 29, 144-155. [CrossRef]

22. Almarashdeh, I. Sharing instructors experience of learning management system: A technology perspective of user satisfaction in distance learning course. Comput. Hum. Behav. 2016, 63, 249-255. [CrossRef]

23. Mirriahi, N.; Alonzo, D.; McIntyre, S.; Kligyte, G.; Fox, B. Blended Learning innovations: Leadership and change in one Australian Institutions. Int. J. Educ. Dev. Using Inf. Commun. Technol. 2015, 11, 4-16. Available online: http:/ /ijedict.dec.uwi.edu/viewissue. php?id=41 (accessed on 23 March 2021).

24. Yot, C.; Marcelo, C. University students self-regulated learning using digital technologies. Int. J. Educ. Technol. High. Educ. 2017, 14, 38. [CrossRef]

25. Cohen, L.; Manion, L.; Morrison, K. Research Methods in Education, 7th ed.; Routledge: Oxfordshire, UK, 2011.

26. Chyung, S.Y.Y.; Roberts, K.; Swanson, I.; Hankinson, A. Evidence-Based Survey Design: The Use of a Midpoint on the Likert Scale. Perform. Improv. 2017, 56, 15-23. [CrossRef]

27. Burns, B.A. Students' perceptions of online courses in a graduate adolescence education program. MERLOT J. Online Learn. Teach. 2020, 9, 13-25. Available online: https://jolt.merlot.org/vol9no1/burns_0313.pdf (accessed on 23 March 2021). 
28. Fedynich, L.V.; Bradley, K.S.; Bradley, J. Graduate students' perception of online learning. Res. High. Educ. J. 2015, 27, 1-13. Available online: https:/ / www.aabri.com/manuscripts/142108.pdf (accessed on 23 March 2021).

29. Khan, M.A.; Singh, V.; Nabi, M.K.; Khojah, M.; Tahir, M. Students' perception toward E-learning during COVID-19 pandemic in India: An empirical study. Sustainability 2021, 13, 57. [CrossRef]

30. Said, G.R.E. How did the COVID-19 pandemic affect higher education learning experience? An empirical investigation of learners' academic performance at a university in a developing country. Adv. Hum.-Comput. Interact. 2021, 2021, 6649524. [CrossRef]

31. Bali, S.; Liu, M.C. Students' perceptions toward online learning and face-to-face learning courses. IOP Conf. Ser. J. Phys. Conf. Ser. 2018, 1108, 012094. [CrossRef]

32. Upadhayaya, P.R.; Sharma, B.; Gnawali, Y.P.; Belbase, S. Factors influencing graduate students' perception of online and distance learning in Nepal. Turk. Online J. Distance Educ.-TOJDE 2021, 22, 236-269. [CrossRef]

33. Coman, C.; Tiru, L.G.; Mesegan-Schmitz, L.; Stanciu, C.; Bularca, M.C. Online teaching and learning in higher education during the coronavirus pandemic: Students' perspective. Sustainability 2020, 12, 10367. [CrossRef]

34. Alawamleh, M.; Al-Twait, L.M.; Al-Saht, G.R. The effect of online learning on communication between instructors and students during COVID-19 pandemic. Asian Educ. Dev. Stud. 2020. Ahead of print. [CrossRef]

35. Gopal, R.; Singh, V.; Agrawal, A. Impact of online classes on the satisfaction and performance of students during the pandemic period of COVID-19. Educ. Inf. Technol. 2021, 26, 6923-6947. [CrossRef] [PubMed]

36. Dendir, S. An online premium? Characteristics and performance of online versus face-to-face students in principles of microeconomics. J. Educ. Bus. 2016, 91, 59-68. [CrossRef]

37. Dendir, S. Performance differences between face-to-face and online students in economics. J. Educ. Bus. 2019, 94, 175-184. [CrossRef]

38. Chemers, M.; Hu, L.; Garcia, B.F. Academic self-efficacy and first year college student performance. J. Educ. Psychol. 2010, 93, 55-64. [CrossRef]

39. Dhawan, S. Online learning: A panacea in the time of COVID-19 crisis. J. Educ. Technol. Syst. 2020, 49, 5-22. [CrossRef]

40. Ioannou, A.; Demetriou, S.; Mama, M. Exploring factors influencing collaborative knowledge construction in online discussions: Student facilitation and quality of initial postings. Am. J. Distance Educ. 2014, 28, 183-195. [CrossRef] 